\title{
KŪNO KULTŪROS MOKYTOJŲ PROFESINIO PERDEGIMO PREVENCIJA IR REDUKAVIMAS: UGDOMOJO PROJEKTO REZULTATAI
}

\author{
Andrius Stočkus \\ Klaipédos universitetas
}

\begin{abstract}
Anotacija
Straipsnyje siekiama atskleisti kūno kultūros mokytojų profesinio perdegimo prevencijos ir redukavimo galimybes, empiriškai pagrindžiant relaksacinių igūdžių ugdymu paremtos programos efektyvumą tarp Lietuvos bendrojo ugdymo įstaigose dirbančiu kūno kultūros pedagogų. Pastaraisiais metais atlikti tyrimai rodo, kad profesinis perdegimo sindromas pedagogams tapo labai aktuali problema. Nuolat ieškoma būdų, kurie vaidintų prevencinị ir redukcinị vaidmenị šiame procese. Iš visų strategijų vis didesnio mokslininkų dėmesio sulaukia profesinio perdegimo išvengimo, ịveikimo, jo padarinių mažinimo būdai, kuriais žmogus gali padèti sau pats, be kitų pagalbos. Straipsnyje pristatomi ugdomojo projekto, kuriame dalyvavo 23 kūno kultūros mokytojai, rezultatai.

PAGRINDINIAI ŽODŽIAI: kūno kultūra, profesinis perdegimas, relaksacija, redukcija.
\end{abstract}

\begin{abstract}
The article aims at revealing the possibilities for prevention and reduction of physical education teachers' professional burnout by empirically grounding the efficiency of the strategy based on development of relaxation skills of physical education pedagogues working in comprehensive education institutions in Lithuania. Research cases carried out in recent years show that the syndrome of professional burnout is a highly urgent problem among pedagogues. Methods to prevent and reduce the burnout are being constantly sought for. Among all strategies, increased attention of researchers is focused on ways to avoid, cope with and diminish the impact of professional burnout which would enable a person to help oneself without others' assistance. The article presents the results of an educational project which involved 23 teachers of physical education.

KEYWORDS: physical education, professional burnout, relaxation, reduction.
\end{abstract}

\section{Ivadas}

Vis sparčiau šiuolaikiniame pasaulyje vykstantys pokyčiai keičia ir viso edukacinio proceso suvokimą. Informacinès technologijos, tiesiogine konkurencija paremta darbo filosofija, ekonominiai veiksniai, švietimo sistemos reformos keičia mokytojo vaidmeni šių dienų ugdymo sistemoje. Nors visa tai visuomenès gyvenimą tūrètų veikti teigiamai, tačiau neišvengiamai pasireiškia ir neigiami tokių pokyčių padariniai. Ypač aktualios problemos, susijusios su pedagogo asmenybe, emocijomis, psichine ir fizine sveikata. Šiandien vis aktualesni tampa mokslo tyrimai, kurie padeda atskleisti ir identifikuoti psichologinio pobūdžio problemas, susijusias su pagrindiniu ugdymo proceso dalyviu - mokytoju (Tonder, Williams, 2009). Šiuolaikinis mokytojas - tai žmogus, turintis daugybę pareigų ir tik mini- 
malias teises, neužtikrintas dèl savo darbo, nuolat kamuojamas netikrumo jausmo, blaškomas įvairių naujovių ir reformų labirintuose. Nežinomybès jausmas, neadekvatus mokytojo profesijos įvaizdis visuomeneje, nepažangūs ugdytiniai, rūpesčiai dèl darbo vykdymo terminų, skubejjimas, kvalifikacijos kẻlimas - tai tik keletas veiksnių, darančių itaką darbinio streso raiškai mokytojo profesinèje veikloje, emociniam ir fiziniam išsekimui, pervargimui (Bubelienè, 2010). Viso to rezultatas dažnai apibūdinamas viena sąvoka - perdegimu, kuris nebeatsiejamas nuo pedagogo profesinès veiklos (Coulter, Abney 2009; Mukundan, Khandehroo, 2010).

Iš 4800 Olandijos valstybès tarnautojų, 1998 metais pripažintų netinkamais darbui, 38 \% buvo mokytojai (Magnée, 2000; cit. remiantis Brouwers, Tomic, Boluijt, 2011). Ivairūs tyrimai, atlikti Didžiojoje Britanijoje, Olandijoje, Skandinavijoje, JAV, Australijoje, Kanadoje, Naujojoje Zelandijoje ir kitose šalyse, rodo, kad apie trečdalis mokytojų kenčia dèl nuolatinès itampos darbe (Papastylianou, Kaila, Polychronopoulos, 2009). Didžiojoje Britanijoje 66 \% mokytojų per savo karjerą yra mastę apie išějimą iš darbo. Olandijoje $60 \%$ mokytojų, kurie išèjo iš darbo, kentejo nuo profesinio perdegimo (Papastylianou, Kaila, Polychronopoulos, 2009).

Perdegimo tema vis labiau domina akademinę bendruomenę. Stengiamasi identifikuoti šio nemalonaus reiškinio požymius, raiškos veiksnius ir priežastis, labiausiai pažeidžiamas profesijų ir pavienių individų grupes, kurioms perdegimo sindromo rizika yra didesnè. Tačiau trūksta tyrimų, kuriuose būtų pasiūlytos strategijos, galinčios padèti individui silpninti perdegimo sindromą ar jo išvengti. Mokslinių tyrimu, kuriuose ieškoma atsakymų i klausimus, kaip išvengti ar silpninti perdegimo sindromą, nedaug.

\section{Profesinis perdegimas kaip psichosocialinis fenomenas}

Profesinio perdegimo ar tiesiog perdegimo (angl. burnout) sąvokos vis dažniau aptinkamos moksliniuose tyrimuose, kurių objektu pasirenkami pedagogai. Tyrimais (Maslach, Leiter, 1997; Maslach et al., 2001; Näring et al., 2006; Brudnik, 2009; Tonder, Williams, 2009; Coulter, Abney, 2009; Chang, 2009; Papastylianou, Kaila, Polychronopoulos, 2009; Mukundan, Khandehroo, 2010; Özbey, 2012; Rey, Extremera, Pena, 2012; Sulea et. al., 2012) nustatyta, kad mokytojo profesija neatsiejama nuo perdegimo sindromo ir įvardijama kaip viena labiausiai pažeidžiamu, kalbant apie ši nemalonų reiškini. Nors profesinio perdegimo apibrèžimų yra daug, viena žinomiausių šio sindromo tyrẻjų C. Maslach pateikẻ apibrèžimą, kuris tapo populiariausiu ir visuotinai pripažintu akademineje bendruomeneje. Perdegimas tai emocinio, psichinio ir fizinio išsekimo būsena, atsiradusi veikiant ilgalaikiams 
neišspręstiems stresams, kylantiems darbo situacijose (Maslach, 1993). Tai užsitęsęs atsakas ị ịsisenèjusius (nuolatinius) emocinius ir tarpasmeninius stresorius darbe, kurie apibūdinami trimis dimensijomis: emociniu išsekimu, depersonalizacija ir asmeninių profesinių siekių sumažejjimu (Maslach et al., 2001). Tai daugiamatis reiškinys, apimantis tris dimensijas:

- emocini išsekimą (angl. emotional exhaustion);

- depersonalizaciją (angl. depersonalization);

- asmeninių profesinių siekių sumažėjimą (angl. personal accomplishment).

Emocinis išsekimas (EE) - tai emocinis persidirbimas, savų emocinių išteklių išeikvojimas. Tai jausmas, kai žmogus, bendraudamas su kitais, nebepajejgia vykdyti jam keliamų reikalavimų, pasijunta visiškai emociškai ir fiziškai išsekęs ir dẻl to jaučia frustraciją (nusivylima) bei įtampą. Žmogui trūksta energijos imtis naujos veiklos ar bendrauti su kitu žmogumi. Išsekimas yra pirmoji reakcija $\mathfrak{i}$ stresą, kuri jis patiria darbe. Emocinis išsekimas laikomas pagrindiniu perdegimo sindromo komponentu (Maslach et al., 2001).

Depersonalizacija (DP) reiškiasi neigiamu, cinišku elgesiu, emociniu atsitraukimu, apimančiu nusivylimą, nepasitikèjimą, neviltinguma, arba perdètu šaltumu bendraujant su kitais žmonėmis darbe. Tai abejinga žmogaus reakcija i žmones, su kuriais dirba, santykiai su žmonėmis tampa formalūs, tarsi beasmeniai. Tam tikra prasme taip reiškiasi siekis apsisaugoti nuo išsekimo ir nusivylimo. Depersonalizacijos komponentas reiškia tarpasmenini perdegimo aspektą. Jis dar vadinamas dehumanizacija.

Asmeninių profesinių siekių sumažèjimas (PA) - tai savo kompetencijos ir produktyvumo, efektyvumo jausmo sumažejimas darbe, neveiksmingumas. Tai sumažèjęs pasitikëjimas savo jègomis, kompetencija ir gebejjimu sẻkmingai dirbti, savo pasiekimu ir svarbumo darbe nuvertinimas. Žmogus jaučiasi neefektyvus ir nenaudingas savo darbe ir mano, kad jo asmeninis įnašas į organizacijos veiklą nebesvarbus (Nagar, 2012). Asmeniniu siekių sumažėjimo jausmas reiškia savęs vertinimą perdegimo raiškos aspektu.

Nors pirmieji moksliniai perdegimo tyrimai pradèti aštuntojo (praeito amžiaus) dešimtmečio pradžioje, intensyviai pedagogu profesiniu perdegimu imta domètis tik po dešimties metų. Ankstyvieji tyrimai esmine mokytojų profesinio perdegimo priežastimi laikè darbo krūvị (Chang, 2009), tačiau laikui bėgant nustatytos kelios mokytojų profesinio perdegimo tyrimų kryptys, atsižvelgiant i tai, kokios priežastys daro ittaką profesinio perdegimo pasireiškimui. Tai individualūs (sociodemografiniai kintamieji, asmenybės savybès ir pan.) ir organizaciniai (darbo sąlygos, krūviai, ryšių su kitais žmonėmis sudètingumas ir pan.) veiksniai. Šiuolaikiniai mokytojų profesinio perdegimo tyrimai labiau orientuoti į mokytojų perdegima, 
kaip pavienių veiksnių (individualių ir organizacinių) sąveikos rezultatą (Chang, 2009).

\section{Pedagogų profesinio perdegimo prevencijos ir redukavimo profesinėje veikloje galimybės}

Siekiant nustatyti profesinio perdegimo priežastis, natūraliai kyla klausimas, kaip išvengti šio nemalonaus reiškinio gyvenime? D. D. Zellmer (2005) teigimu, visų pirma, mokytojai turètų pripažinti, kad jie kenčia nuo perdegimo sindromo (jei pasireiškia konkretūs požymiai). Taip immanomas ankstyvas įsikišimas ir konstruktyvios profesinio perdegimo prevencijos ar redukcijos strategiju paieškos. Mokslininkai (Водопьянова,Старченкова, 2008) teigia, kad profesinio perdegimo išvengimo, i̇veikimo, jo padarinių mažinimo būdus galim suskirstyti ị dvi kryptis: 1) tai pagalba, kurią sau gali suteikti pats žmogus (savipagalba) ir 2) pagalba, kurią gali suteikti tos srities profesionalas. Pirmuoju atveju žmogus turi būti susipažinęs su ittampos, streso, perdegimo pasireiškimo požymiais (simptomais), gebèti juos identifikuoti ir būti įvaldęs savireguliacijos metodus, kurie padètų valdyti patiriamą stresą, itampą ir kitas nemalonias būsenas. Jei tokia pagalba neduoda teigiamo efekto, būtina naudotis profesionalia pagalba (psichologo, psichoterapeuto), kurią gali suteikti kiti asmenys.

Teigiama (Cohen, Gagin, 2005; Stueck, 2010), kad strategijų, kurios padètų sumažinti neigiamą profesinio perdegimo poveikị ar užkirsti kelią šiam nemaloniam reiškiniui, yra nepakankamai. Kadangi pedagogu profesinis perdegimas pradètas tyrinèti neseniai (devintasis praeito amžiaus dešimtmetis), prevencijos ar ịveikos strategijos susilaukia mažai mokslininkų dėmesio. Kalbant apie profesinio perdegimo įveikimo, redukavimo strategijas, kuriomis gali pasinaudoti nuo šio reiškinio kenčiantis asmuo, skiriamos populiariausios strategijos, suteikiančios tam tikras kompetencijas (savistaba, savireguliacija, gebejimas pajusti įtampą ir ją šalinti). Galima paminèti atsipalaidavimo technikas, tokias kaip streso, fizinès ir emocinès ịtampos valdymas, koncentracija, meditacija, kurios padidina saviefektyvumą, kovojant su neigiamomis emocinėmis būsenomis, stresu ir perdegimu. Tai vienas veiksmingiausių vidinès įtampos, nerimo, streso ar net depresijos valdymo būdų. Atsipalaidavimas (angl. relaxation) apibūdinamas kaip ramybès būsena, kai po didelių dvasinių išgyvenimų arba sunkaus fizinio darbo nelieka nervinès įtampos (Psichologijos žodynas, 1993). Atsipalaidavimas, dar įvardijamas tarptautiniu relaksacijos terminu, gali būti nevalingas (žmogus atsipalaiduoja užmigdamas) arba valingas (žmogus atsisèda arba atsigula ir ịsivaizduoja situacijas, kurios jam suke- 
lia ramybės pojūtị). Mokslininkų (Bieliauskaitė Jarašiūnaite, 2009) teigimu, atsipalaidavimą galima apibrèžti kaip psichologinès ir fiziologinès ịtampos sumažèjima. Atsipalaidavimo metu, organizme vyksta tam tikri fiziologiniai ir psichologiniai procesai. Atsipalaidavimas, arba relaksacija, yra seniausias ir populiariausias itampos valdymo būdas (Smith, 2007). Žmogui atsipalaidavus nustojama eikvoti energija tam tikrų raumenu itempimui palaikyti, lengviau valdomas (sutelkiamas) dẻmesys, žmogus nurimsta, stabilizuojasi psichika ir psichiniai procesai, teigiamai veikiama protinè bei emocinè būklè.

Mokslininkai (Cherniss, 1993; Maslach et al., 2001) pabrèžia, kad šios kompetencijos (pvz., savistaba, savireguliacija) didina žmogaus saviefektyvumą kovojant su profesiniu perdegimu. Saviefektyvumo sąvoka apibrèžiama (Bandura, 1997) kaip tikèjimas savo gebejimais organizuoti ir atlikti veiksmus, kurie būtini ko nors siekiant. Saviefektyvumas, mokslininkų (Cherniss, 1993; Maslach et al., 2001) teigimu, vaidina pagrindini i̇veikiant profesini perdegimą. O i̇vairių atsipalaidavimo, koncentracijos ir kitų technikų mokymasis didina žmogaus saviefektyvumo jausmą (Cohen, Gagin, 2005). Tyrimuose (Shapiro, Brown, Biegel, 2007; Ponce et. al., 2008; Campbell et al., 2009; Froeschle, Crews, 2010; Gold et al., 2010; Stueck, 2010), kur ieškoma atsakymu, kaip išvengti itampos ar įveikti stresą, profesini perdegima, dominuoja strategijos, kurios remiasi ịvairiais atsipalaidavimo, savireguliacijos (gebejimas atsipalaiduoti, valdyti savo psichinius ir fiziologinius procesus (Grakauskas, 2004, cit. remiantis Bieliauskaitè, Jarašiūnaite, 2009) metodais. Savireguliacijos, relaksaciniai gebejjimai padeda valdyti ir silpninti fizinę bei psichinę itampa, moko atsipalaiduoti. Stresas sukelia tam tikrus autonominės sistemos pokyčius, tokius, kaip padidejęs širdies ritmas, kraujo spaudimas, kvejpavimas, raumenu i̇tampa, padidẻjęs prakaito liaukų aktyvumas, šaltos rankos ir pédos (Calderon, Thompson, 2004, cit. Remiantis Bieliauskaitè, Jarašiūnaitè, 2009). Individai gali išmokti valdyti šias i stresą reaguojančias funkcijas.

Būtina paminèti ir tai, kad atsipalaidavimas - tai ne streso neutralizavimas, šių mokymų paskirtis - sumažinti ne pati stresą, o žmogaus reakciją i ji. Naudojama daugybė atsipalaidavimo būdų. Kai kurie atsipalaidavimo pratimai atliekami individualiai, kiti atliekami su profesionalo pagalba. Atsipalaidavimo psichoterapinis efektas, mokslininkų (Курис, 2001) teigimu, pasiekiamas sistemiškai taikant metoda, kuris leidžia kiekvienam individui pasirinkti optimalią atsipalaidavimo metodika.

Relaksacinių igūdžių mokymusi paremta perdegimo prevencijos ir redukcijos strategija turi keletą privalumų. Pagrindinis šio metodo privalumas - mokymas atsipalaiduoti yra vienas paprasčiausių ir saugiausių savireguliacijos būdų, kuriems nereikia ypatingu gebejjimų ar papildomų ištekliu (pvz., pinigu), be to, besimo- 
kančiajam duoda pakankamai greitą efektą. Tačiau tokio pobūdžio strategijos bus efektyvios esant tinkamam motyvaciniam klimatui (stipri mokymosi motyvacija).

Tyrimo problema - dabartinejje mokslinèje literatūroje dar vis trūksta išsamių, sisteminių, empirinių tyrimų apie pedagogų profesinio perdegimo prevencijos ir îveikos būdus edukacinèje veikloje. Šiai problemai atskleisti reikia gilesnès empirinès analizès, kad būtų galima atsakyti probleminị klausimą, ar relaksacinių igūdžiu mokymusi (skatinant kūno kultūros mokytojų savišvietą, mokymąsi visą gyvenimą, kritini mąstymą) paremta programa yra efektyvi, siekiant užtikrinti kūno kultūros pedagogų profesinio perdegimo prevenciją ir redukciją?

Tyrimo objektas - kūno kultūros mokytojų profesinio perdegimo prevencijos ir redukavimo programa.

Tyrimo tikslas: sudaryti profesinio perdegimo prevencijos ir redukavimo programą, empiriškai pagrịsti jos poveikio (ne)efektyvumą, skatinant kūno kultūros mokytojų savišvietą, mokymąsi visą gyvenimą, kritinį mąstymą bei ugdant relaksacinius igūdžius.

\section{Tyrimo metodologija}

\subsection{Imtis}

Ugdomojo projekto dalyvių imčiai sudaryti naudotas kokybinio tyrimo imties sudarymo būdas - kriterinè atranka (angl. criterion sampling) (Bitinas, 2006, Rupšienè, 2007). Ugdomojo projekto programą vykdė dvidešimt trys (23) Šiauliu miesto bei rajono bendrojo ugdymo isstaigose dirbantys kūno kultūros mokytojai, 10 vyrų ir 13 moterų, kurių amžius - nuo 28 iki 52 metų, darbo stažas - 1-29 metai, vidutinis darbo krūvis mokymo įstaigoje - 22,78 valandų per savaitę. Mokytojo pedagoginę kvalifikaciją turejo 5 pedagogai, mokytojo metodininko - 18 . Visi mokytojai, dalyvavę projekte, turi šeimas ir, išskyrus kūno kultūros mokytojo darbą, neužsiima jokia kita veikla. Du (2) mokytojai dirba pagrindineje, 9 - vidurinejje mokykloje, 12 - gimnazijoje.

\subsection{Ugdomasis projektas}

Kūno kultūros mokytojų profesinio perdegimo prevencijos ir redukavimo programos empiriniam pagrindimui ir jos poveikio (ne)efektyvumui ịvertinti pasirinktas ugdymo projekto metodas (Bitinas, 2006).

Ugdomojo projekto relaksacijos programos turini (1 paveikslas) sudaro teorinè ugdomosios programos dalis ir praktinè - keturi atsipalaidavimo būdų blokai: 
kvėpavimo pratimai; vizualizacija; raumenų tonuso keitimo igūdžiai; autogeninè treniruotè. Ugdomojo projekto relaksacijos programos atsipalaidavimo būdų blokai skirti mažinti fizinę ir psichinę itampą; progresuojanti raumenų relaksacija ir kvėpavimo pratimai - užtikrinti fizinès ittampos redukciją; autogeninè treniruotè ir vizualizacija - psichinès įtampos redukciją.

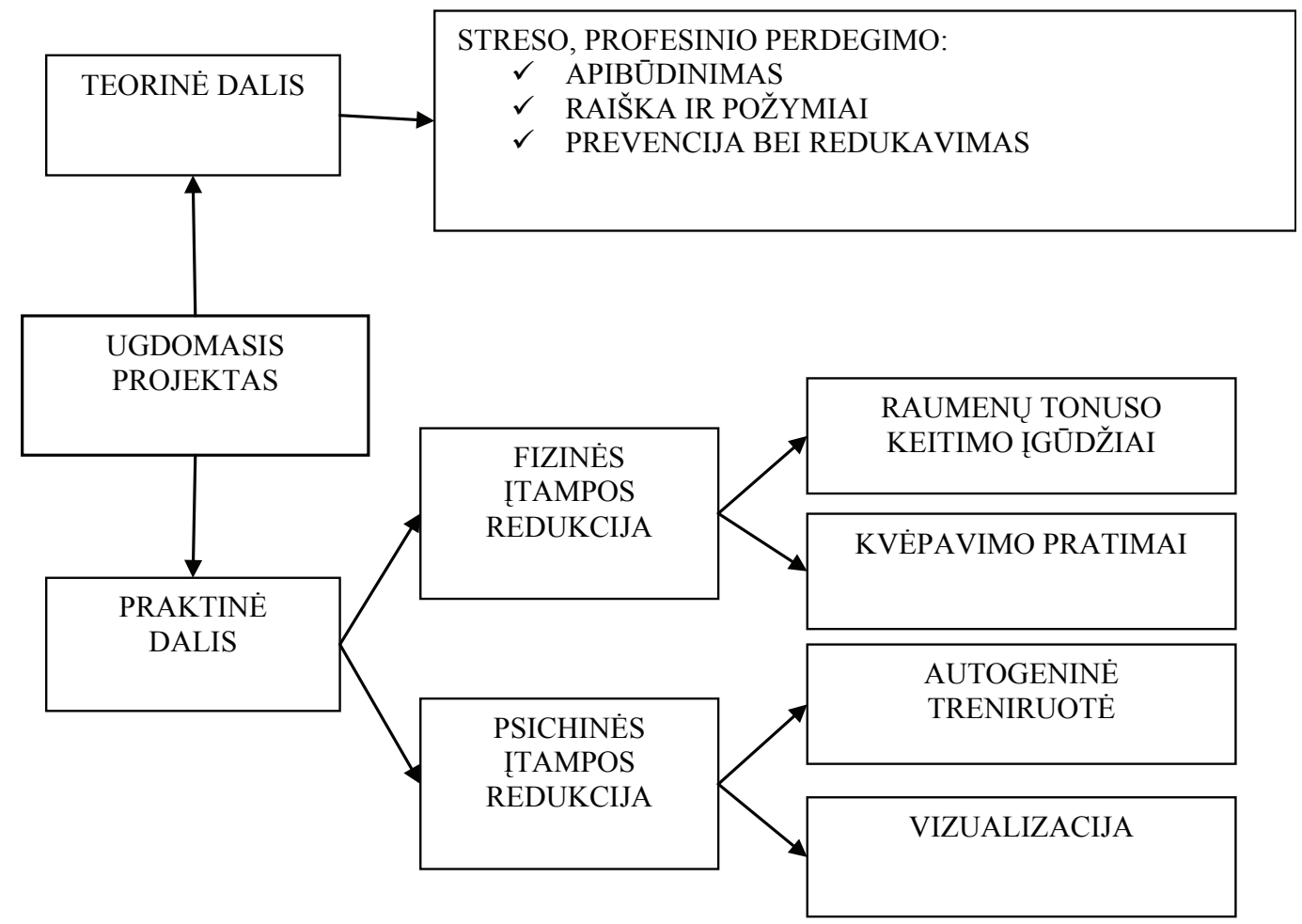

1 pav. Ugdomojo projekto programos turinys

Figure 1. Content of the educational project's programme

Kiekvienas atsipalaidavimo būdų blokas sudarytas iš tam tikrų atsipalaidavimo pratimų (iš viso - 23 pratimai) ir papildomos informacijos - pratimo atlikimo metodinių rekomendacijų (atsipalaidavimo pratimų skaičius, jų atlikimo trukmės intervalai ir pan.). Pratimų atlikimo trukmès intervalai ugdomajame projekte griežtai nereglamentuoti, pratimų atlikimo laiko intervalai projekto dalyvių galèjo būti koreguojami, atsižvelgiant $i$ asmeninius poreikius.

Ugdomojo projekto trukmè - 24 savaitès. Pirmają savaitę kūno kultūros pedagogams pateikta visa su ugdomojo projekto veikla susijusi informacija. Vykdant ugdomaji projektą atlikti du diagnostiniai pjūviai (pirmasis - pirmają ugdomojo 
projekto savaitę, antrasis - paskutiniają savaitę) ir du etapiniai ugdomojo projekto tyrimai ( 8 ir 16 savaitès). Ugdomojo projekto intervenciniams pokyčiams įvertinti naudoti klausimynai (Maslach perdegimo aprašas - pedagogo apklausa, subjektyviai suvokto streso skale $S U D S$ ir mokymosi įsivertinimo skale $M I S$ ), prašyta refleksijas pateikti raštu.

Refleksijų raštu metodu siekta ugdomojo projekto dalyvių grižtamojo ryšio, kalbant apie dalyvavimo ugdomajame projekte procesa, mokymosi eiga, sunkumus, programos trūkumus ir privalumus, tinkamiausias atsipalaidavimo priemones kiekvienam projekto dalyviui. Be to, siekta patikrinti ugdomosios programos veiksmingumą (pavieniu jos poveikio priemonių veiksmingumo ir dermès su kitomis ugdomosios programos poveikio priemonėmis) profesinio perdegimo prevencijai ir redukcijai. Gauta medžiaga leistų išryškinti ir pagrịsti efektyviausias ugdomosios programos poveikio priemones, kurias taikant būtu galima veiksmingai redukuoti ir išvengti profesinio kūno kultūros mokytojų perdegimo. Refleksijoms raštu apdoroti taikytas turinio analizès (angl. content analysis) metodas.

Profesiniam perdegimo sindromui nustatyti naudotas Maslach perdegimo aprašas - ES (angl. Maslach Burnout Inventory - MBI) (Maslach et al., 1996). Iš visų sukurtų perdegimo sindromo tyrimo instrumentų MBI yra populiariausia moksliniuose tyrimuose taikoma metodika, pasižyminti stipriausiomis psichometrinėmis savybèmis. Aprašą sudaro 22 teiginiai, matuojantys tris perdegimo sindromo dimensijas: emocini išsekimą, depersonalizaciją ir asmeninių laimejjimu sumažejimo jausmą. Kiekvienas klausimyno teiginys vertinamas Likerto dažnumo skale: nuo 0 (niekada) iki 6 (kasdien). Emocinio išsekimo ir depersonalizacijos skalių didesni įverčiai reiškia aukštesnį perdegimo sindromo lygị. Asmeninių laimejjimų sumažejjimo skalès mažesni įverčiai reiškia aukštesni perdegimo sindromo lygi. Klausimyno skalių vidinis suderinamumas (angl. Cronbachalpha) yra pakankamai geras, svyruoja nuo 0,79 iki 0,87 .

Subjektyviai suvokiamo streso skalè (SUDS) (Williams, Poijula, 2002). Subjektyviai suvokiamas individo jaučiamas stresas matuojamas pagal dešimties balų skalę. Respondentas gali nusakyti savo būseną pagal patiriamą (subjektyviai suvokiama) įtampą /stresą „čia ir dabar“ nuo nulio (0) - „Aš esu visiškai atsipalaidavęs, nejaučiu įtampos, streso“, iki dešimties (10) - „Didžiausias įtampa /stresas, kurị esu kada nors jautęs(-usi)“.

Mokymosi įsivertinimo skalè (MIS). Autoriaus sudaryta skale, leidžianti ugdomojo projekto dalyviui subjektyviai ivertinti (isivertinti) ugdomojo projekto programos igyvendinimą ir nustatyti laikotarpi, per kurį ugdomojo projekto dalyvis išmoko atitinkamų atsipalaidavimo pratimų. Mokymosi ịsivertinimo skale - tai 
ugdomosios programos tam tikrų pratimų mokymosi ir tobulinimo stebėsena kiekvieną dieną visą ugdomojo projekto vykdymo laiką. Pagal penkių balų skalę galima ísivertinti savo gebejjimus ir pojūčius nuo vieneto (1) - „Sekasi blogai“, iki penketo (5) - „Taikau ši metodą (pratimą) kai man to reikia“.

Tyrimo duomenys apdoroti statistinès analizès metodais(kiekybinio tyrimo duomenų analizė atlikta naudojant kompiuterinį statistini programų paketą SPSS 16.0 [angl. Statistical Package for Social Sciences]).

\subsection{Tyrimo rezultatai ir jų aptarimas}

Ugdomojo projekto intervenciniams pokyčiams įvertinti taikytas apklausos raštu metodas. Apklausa raštu taikyta vertinant diagnostinius pjūvius (DP) ir etapus (ET), siekiant ịvertinti ugdomojo projekto dalyvių (kūno kultūros mokytojų) patiriamo (patirto) profesinio perdegimo lygmeni (MBI-ES) viso ugdomojo projekto metu.

Siekiant objektyviau įvertinti kūno kultūros mokytoju patiriamo profesinio perdegimo lygi, nuspręsta patikrinti, ar ugdomojo projekto dalyviu apklausos (MBI-ES) rezultatai skirtinguose tyrimo etapuose tiesiogiai nesusiję su emocine mokytojų būsena „čia ir dabar“, t. y. su būsena klausimyno (MBI-ES) pildymo metu. Tam tikslui naudotas SUDS klausimynas. Siekta atskleisti, ar mokytojo emocinè būsena klausimyno (MBI-ES) pildymo dieną nesusijusi (neturi įtakos) su MBI-ES rezultatais. Kiekvienas ugdomojo projekto dalyvis kartu pilde ir SUDS skalę, taip nustatydamas savo būseną pagal subjektyviai suvokiamą stresą „,̌ia ir dabar". Atlikus Maslach perdegimo aprašo-pedagogo apklausos (MBI-ES) ir subjektyviai suvokiamo streso skalès (SUDS) rezultatų tarpusavio ryšio analizę (Spearman koreliacijos koeficientas), nustatyta, kad egzistuoja silpnas MBI-ES klausimyno (visų skaliu) ir SUDS rezultatų tarpusavio ryšys tiek pirmojo, tiek ir antrojo diagnostiniu pjūvių metu. Taigi galima teigti, kad ugdomajame projekte dalyvaujančiu kūno kultūros mokytojų MBI-ES rezultatams (profesinio perdegimo lygiui) emocinė pedagogų būsena ,čia ir dabar“ (patirti išgyvenimai ar kiti veiksniai) neturejo beveik jokios itakos.

Gauti ugdomojo projekto pirmojo ir antrojo diagnostiniu pjūvių rezultatai pateikti pirmoje lentelèje. 
1 lentelè. Ugdomojo projekto pirmojo ir antrojo diagnostinių pjūvių, Maslach perdegimo aprašo-pedagogo apklausos (MBI-ES) statistiniai rodikliai Table 1. Statistical indexes of the first and the second sections of the educational project, Maslach burnout syndrome description-survey of a pedagogue (MBI-ES)

\begin{tabular}{|c|c|c|c|c|c|c|c|}
\hline $\begin{array}{l}\text { Profesinio } \\
\text { perdegimo } \\
\text { dimensijos }\end{array}$ & $\begin{array}{c}\text { Diagnostiniai } \\
\text { pjūviai }\end{array}$ & $\mathrm{N}$ & $\begin{array}{l}\text { Vidurkio } \\
\text { reikšmè }\end{array}$ & $\begin{array}{c}\text { Standartinis } \\
\text { nuokrypis }\end{array}$ & $\begin{array}{l}\text { Standartinè } \\
\text { paklaida }\end{array}$ & \begin{tabular}{|c|}
$t$ \\
kriterijaus \\
reikšmé \\
\end{tabular} & $\begin{array}{c}\text { Patikimumo } \\
\text { lygmuo } p\end{array}$ \\
\hline \multirow{2}{*}{$\begin{array}{l}\text { Emocinis } \\
\text { išsekimas }\end{array}$} & Pirmasis & 18 & 21,22 & 12,85 & 3,02 & \multirow{2}{*}{2,493} & \multirow{2}{*}{$\begin{array}{c}0,023 \\
\boldsymbol{p}<\mathbf{0 , 0 5}\end{array}$} \\
\hline & Antrasis & 18 & 15,16 & 4,7 & 1,12 & & \\
\hline \multirow{2}{*}{ Depersonalizacija } & Pirmasis & 18 & 11,55 & 5,81 & 1,37 & \multirow{2}{*}{1,994} & \multirow{2}{*}{$\begin{array}{c}0,062 \\
p>0,05\end{array}$} \\
\hline & Antrasis & 18 & 10,27 & 3,89 & 0,91 & & \\
\hline \multirow{2}{*}{$\begin{array}{c}\text { Asmens } \\
\text { profesinių siekių } \\
\text { sumažejjimas }\end{array}$} & Pirmasis & 18 & 28,50 & 7,57 & 1,78 & \multirow{2}{*}{$-3,781$} & \multirow{2}{*}{$\begin{array}{c}0,001 \\
\boldsymbol{p}<\mathbf{0 , 0 5}\end{array}$} \\
\hline & Antrasis & 18 & 36,72 & 5,02 & 1,18 & & \\
\hline
\end{tabular}

Pakartotinų matavimų $t$-testo (tam tikrose Maslach perdegimo aprašo-pedagogo apklausos instrumento skalèse) rezultatai atskleide, kad statistiškai reikšmingas rezultatų skirtumas egzistuoja emocinio išsekimo (EE) $(t=2,493, p<0,05)$ ir asmens profesinių siekių mažèjimo (PA) $(t=-3,781, p<0,05)$ skalèse. Depersonalizacijos (DP) skalès rezultatai statistiškai reikšmingai tarp pirmo ir antro diagnostinių pjūvių nesiskiria $(t=1,994, p>0,05)$. Interpretuojant gautus rezultatus galima teigti, kad kūno kultūros mokytojų, dalyvavusių ugdomajame projekte, emocinio išsekimo ir asmens profesinių siekių mažèjimo lygis reikšmingai sumažèjo projekto pabaigoje, tačiau depersonalizacijos lygis išliko labai panašus, nors MBI-ES depersonalizacijos skalès antrojo diagnostinio pjūvio rezultatų vidurkis $(10,27)$ mažesnis nei pirmojo (pre-test) tyrimo $(11,55)$.

Siekiant ivvertinti bendrą ugdomojo projekto eigos apklausos raštu kiekybinę dinamiką atlikti ir etapiniai tyrimai ( 8 ir 16 ugdomojo projekto savaitemis). Visu apklausos raštu MBI-ES tyrimų (diagnostinių pjūvių ir etapinių tyrimų) rezultatai atskleide, kad viso ugdomojo projekto metu emocinio išsekimo (EE) ir asmeniniu profesinių siekiu sumažèjimo jausmo (PA) rodikliai nuolat mažèjo. Depersonalizacijos (DP) rodikliai, atliekant pirmaji diagnostini pjūvị ir pirmojo etapo tyrimą nepakito, tačiau atliekant antrojo etapo tyrimą ir antraji diagnostini pjūvị buvo mažesni nei pre-test tyrimo.

Analizuojant ugdomojo projekto dalyvių MBI-ES rezultatus, atkreiptas dèmesys į visų instrumento skalių rezultatų vidurkių standartinius nuokrypius. Statistikoje standartinis nuokrypis (angl. standart deviation) apibréžiamas kaip dydis, kuris parodo, kaip gautų duomenų (atsitiktinio dydžio) igyjamos reikšmės pasiskirsto 
apie vidurkị. Mažas standartinis nuokrypis rodo, kad reikšmės, pasiskirsčiusios arti vidurkio, t. y. rezultatai yra artimesni vienas kitam. Iš gautų rezultatų (1 lentelè) matyti, kad visų MBI-ES skalių rezultatų (visų tyrimo etapu) vidurkių standartiniai nuokrypiai tolygiai mažejja. Pirmojo diagnostinio pjūvio emocinio išsekimo (EE) rezultatų vidurkio standartinis nuokrypis - 12,85, antrojo diagnostinio pjūvio - 4,78, atitinkamai depersonalizacijos (DP) - 5,81 ir 3,89 bei asmeninių profesiniu siekių sumažejjimo (PA) - 7,57 ir 5,02. Tuo remiantis galima teigti, kad ugdomojo projekto pabaigoje kūno kultūros mokytojams lavinant relaksacinius igūdžius jų profesinio perdegimo rodikliai, projektui pasibaigus, supanašejo teigiamai, t. y. profesinio perdegimo lygmuo sumažejo.

\subsection{Refleksijų raštu rezultatai}

Apibendrinant ugdomojo projekto metu gautų refleksijų analizès rezultatus, galima teigti, kad:

- visi ugdomojo projekto dalyviai teigiamai ivvertino ugdomosios programos poveiki streso ir profesinio perdegimo prevencijai bei redukcijai;

- teorinès ugdomosios programos žinios (ypač apie streso ir profesinio perdegimo prevenciją bei redukavimą atsipalaidavimo pratimais) buvo pagrindinis motyvas, skatinęs pedagogus dalyvauti projekte (siekti įvaldyti relaksacijos igūdžius);

- kaip veiksmingiausios itampos mažinimo ir atsipalaidavimo priemonès (dèl savo paprastumo ir greito efekto)ivardytos kvépavimo bei vizualizacijos technikos;

- raumenų tonuso keitimo igūdžių ir autogeninès treniruotès pratimai ịvardyti kaip sudėtingesni, tačiau taip pat veiksmingi ịtampos šalinimo būdai;

- ugdomasis projektas parode, kad pedagogams prireikè apytikriai vieno mėnesio, kad išmoktų taikyti kvėpavimo, autogeninès treniruotès ir vizualizacijos technikas, išmokti raumenų tonuso keitimo igūdžiu technikos prireikè beveik dvigubai daugiau laiko (du mènesiai);

- kvėpavimo relaksacijos pratimai buvo pagrindinè atsipalaidavimo technika, papildanti kitus atsipalaidavimo pratimus; vizualizacijos technikos sẻkmingai papildè autogeninès treniruotès ir raumenų tonuso keitimo igūdžių mokymąsi;

- ugdomajam projektui pasibaigus kūno kultūros pedagogai gebèjo nusistatyti įtampą savo kūne ir ją sèkmingai šalinti bei redukuoti;

- pagrindinès ugdomosios programos pritaikymo galimybès taikant streso ir profesinio perdegimo prevenciją bei redukavimą: a) itampos ir neigiamu 
emocijų redukcija po darbo dienos; b) psichosomatinių sutrikimų redukcija ir nemigos i̇veika; c) žvalumo ir energingumo pojūtis dienos pradžioje;

- ugdomasis projektas paskatino pedagogus laikytis dienotvarkès, planuoti savo laiką, ugdè atsakingumo jausmą, taip pat turejjo teigiamos itakos mokytojų bendravimui su savo šeimos nariais;

- ugdomasis projektas kūno kultūros mokytojams suteikè naujų kompetencijų, kurios sẻkmingai realizuotos per kūno kultūros pamokas.

Ugdomasis projektas sudare galimybę empiriškai patikrinti kūno kultūros mokytoju profesinio perdegimo prevencijos ir redukavimo programa, kuri paremta kūno kultūros mokytojų mokymusi visą gyvenimą, savišvietos skatinimu ir pedagogu savireguliacijos (relaksaciniu) gebejjimų ugdymu. Ugdomajame projekte taikyto apklausos raštu metodo rezultatai atskleide, kad kūno kultūros pedagogu, dalyvavusių ugdomajame projekte, emocinio išsekimo ir asmens profesinių siekiu sumažèjimo lygis projekto pabaigoje reikšmingai sumažèjo. Depersonalizacijos lygis išliko labai panašus, nors antrojo diagnostinio pjūvio rezultatų vidurkis mažesnis nei pirmojo diagnostinio pjūvio. Be to, nustatyta, kad emocinio išsekimo ir asmens profesinių siekių sumažejimo lygis viso ugdomojo projekto metu nuosekliai mažèjo. Kalbant apie konkrečias profesinio perdegimo dimensijas būtina pabréžti, kad prevencijos ir redukavimo būdai, siekiant mažinti emocinị išsekimą, depersonalizaciją ir asmens profesinių siekių sumažèjimą, yra skirtingi. Taip yra todèl, kad visi trys profesinio perdegimo komponentai formuojasi skirtingai, kartais nepriklausomai vienas nuo kito (Maslach et. al., 2001).

Mokslininku (Cohen, Gagin, 2005) teigimu, relaksacinėmis technikomis paremtos profesinio perdegimo programos konkrečias jo dimensijas veikia skirtingai. Šiame tyrime pirmo ir antro diagnostiniu pjūvių depersonalizacijos rodikliai kito mažiausiai, lyginant juos su emocinio išsekimo ir asmens profesinių siekių sumažejimo rodikliais. M. Cohen ir R. Gagin (2005) gauti tyrimo rezultatai byloja, kad relaksacijos programai pasibaigus, tiriamujų depersonalizacijos ir asmens profesinių siekių mažèjimo rodikliai buvo geresni nei emocinio išsekimo rezultatai.

Tyrimo duomenys parode ryškius teigiamus emocinio išsekimo, ypač asmens profesinių siekių mažèjimo, rodiklius. Siekiant tokius rezultatus paaiškinti, būtina palyginti relaksaciniu programų sudedamąsias dalis, konkrečiu programu pratimus, atsipalaidavimo pratimų atlikimo trukmę ir kitus veiksnius bei atlikti daugiau tyrimų, nes mokslo darbų šioje srityje nepakanka. Teigiamų rezultatų asmens profesinių siekių mažèjimo skalëje galima prielaida ta, kad ugdomasis projektas suteikè galimybę kūno kultūros mokytojams igyti papildomų kompetencijuc(išmoko atsipalaidavimo būdų ir juos integravo į kūno kultūros pamokas) ir patirties. Tai savo ruožtu mažino šio nemalonaus jausmo lygi, nes asmens profesinių siekių ma- 
žèjimo jausmas pasireiškia sumažèjusiu pasitikejimu savo jẻgomis, kompetencija ir gebẻjimu sèkmingai dirbti, savo pasiekimų ir svarbumo darbe nuvertinimu. Žmogus jaučiasi neefektyvus ir nenaudingas savo darbe ir mano, kad jo asmeninis inašas į organizacijos veiklą nebeturi reikšmès (Nagar, 2012).

Šis tyrimas turi aiškią ateities perspektyvą ir teikia teorini-metodologini pagrindą tolesniems pedagogu profesinio perdegimo tyrimams. Planuojant tolesnius tyrimus būtina numatyti konkrečias profesinio perdegimo prevencijos ir redukcijos programų struktūrines dalis, kitas relaksacines technikas ar poveikio priemones, kurios susijusios su makrolygmens veiksniais (turinčiais itakos profesinio perdegimo raiškai), socialiniu palaikymu, darbinès aplinkos, tarpusavio santykių gerinimu. Jos sèkmingai papildytu jau turimas žinias apie strategijas, paremtas relaksaciniais igūdžiais. Taip pat verta atsižvelgti ir į fizinių (aerobinių bei tempimo) pratimu poveiki profesinio perdegimo prevencijai ir redukavimui, itraukti šiuos pratimus i relaksacinemis technikomis paremtas įveikos strategijas. Tokio tipo tyrimams, kurių išvados nurodo, kad fiziniai (aerobinio pobūdžio) pratimai gali vaidinti prevencini ir redukcinị vaidmeni profesinio perdegimo raiškoje, yra teorinis ir empirinis pagrindas (Johansson, Hassmen, Jouper, 2008; Gerber et al., 2013). Be to, kalbant apie profesini perdegimą, būtina nustatyti labiausiai pažeidžiamas pedagogu grupes. Empiriškai tikrinti profesinio perdegimo prevencijos ir redukavimo strategijų efektyvumą su konkrečiomis pedagogų grupemis (lyties, amžiaus ir kitais aspektais), išskiriant efektyviausias poveikio priemones labiausiai nuo šio reiškinio kenčiantiems mokytojams.

\section{Išvados}

Profesinio perdegimo prevencijos ir redukavimo programa, skatinant kūno kultūros mokytojų savišvietą, kritinį mąstymą, mokymąsi visą gyvenimą bei ugdant relaksacinius igūdžius, teigiamai veikia profesini perdegimą patyrusius pedagogus - profesinio perdegimo lygis sumažèjo. Tarp pirmo ir antro diagnostiniu pjūvių (ugdomojo projekto pradžioje ir pabaigoje) nustatyti statistiškai reikšmingi rezultatu skirtumai emocinio išsekimo ir asmeninių profesinių siekių mažejimo jausmo subskalèse $(p<0,05)$.

Visi ugdomojo projekto dalyviai teigiamai ivertino ugdomosios programos poveiki streso ir profesinio perdegimo prevencijai bei redukcijai. Ugdomajam projektui pasibaigus visi pedagogai gebejjo nusistatyti ịtampą savo kūne ir ją sẻkmingai šalinti bei redukuoti. Dèl savo paprastumo ir greito efekto kaip veiksmingiausios kūno kultūros mokytoju itampos mažinimo ir atsipalaidavimo jausmo patyrimo priemonès buvo įvardytas kvėpavimas ir vizualizacija, jos tapo ir pagrindine 
atsipalaidavimo technika, papildanti kitus atsipalaidavimo pratimus. Ugdomasis projektas kūno kultūros mokytojams suteikė naujų kompetencijų, kurios buvo sèkmingai realizuotos kūno kultūros pamokose. Kaip pagrindinès atsipalaidavimo pratimų pritaikymo galimybės užtikrinant streso ir profesinio perdegimo prevenciją bei redukavimą ivvardyta: įtampos ir neigiamų emocijų redukcija po darbo dienos, psichosomatinių sutrikimų redukcija ir nemigos įveika, žvalumo, energingumo pojūtis dienos pradžioje.

Gauta 20131010

Pasirašyta spaudai 20140214

\section{Literatūra}

Bandura, A. (1997). Self-efficacy: the exercise of control. New York: Freeman.

Bieliauskaitè, I., Jarašiūnaitè, G. (2009). Fiziologiniai pokyčiai, taikant progresuojančią raumenų ir biogrižtamojo ryšio relaksacijas (žvalgomasis tyrimas). Tarptautinis psichologijos žurnalas: biopsichosocialinis požiūris, nr. 4: $119-134$.

Bitinas, B. (2006). Edukologinis tyrimas: sistema ir procesas. Vilnius: Kronta.

Brudnik, M. (2009). Percepcion of self-efficacy and professional burnout in general education teachers. Human movement, nr. 10 (2): 170-175.

Bubelienè, D. (2010). Mokytoju profesinis stresas ir jo redukavimo prielaidos švietimo vadybos bei edukacinemis priemonemis. Daktaro disertacija. Socialiniaimokslai, edukologija (07S). Šiauliai: ŠU.

Campbell, C., Campbell, D., Krierc, D., Kuehlthaua R., Hilmesa T., Stromberger M. (2007). Reduction in burnout may be a benefit for short-term medical mission volunteers. Mental Health, Religion \& Culture, vol. 12 (7): $627-637$.

Chang, M. L. (2009). An Appraisal Perspective of Teacher Burnout: Examining the Emotional Work of Teachers. Educational Psychology Review, vol. 21: 193-218.

Cherniss, C. (1993). Role of professional self-efficacy in the etiology and amelioration of burnout. In: W. B. Schaufeli, C. Maslach, T. Marek (eds.). Professional burnout: Recent developments in theory and research. Washington, DC: Taylor \& Francis.

Cohen, M., Gagin, R. (2005). Can Skill-Development Training Alleviate Burnout in Hospital Social Workers? Social Work in Health Care, vol. 40(4): 83-97.

Coulter, M. A., Abney P. C. (2009). A study of burnout in international and country of origin teachers. International Review of Education, vol. 55: 105-121.

Froeschle, J. G., Crews, C. R.(2010). Examining Teacher Perspectives of Creative Relaxation. Journal of Creativity in Mental Health, vol. 5: 290-304.

Gerber, M., Brand, S., Elliot, C., Trachsler, E. H., Pühse, U., Beck, J. (2013). Aerobicexercisetrainingandburnout: a pilotstudywithmaleparticipantssufferingfromburnout. BMC ResearchNotes, vol. 6(78): 2-9.

Gold, E., Smith, A., Hopper, I., Herne, D., Tansey, G., Hulland, C. (2010). Mindfulness-Based Stress Reduction (MBSR) for Primary School Teachers. Journal of Child and Family Studies, vol. 19: 184-189.

Johansson, M., Hassmen, P., Jouper, J. (2008). Acute Effects of Qigong Exercise on Mood and Anxiety. International Journal of Stress Management, vol. 15(2): 199-207.

Maslach, C. (1993). Burnout: A multidimensional perspective. In: W. B. Schaufeli, C. Maslach, T. Marek (eds.). Professional burnout: Recent developments in theory and research. Washington DC: Taylor \& Francis.

Maslach, C., Leiter, M. P. (1997). The truth about burnout: how organizations cause personal stress and what to do about it. San Francisco: Jossey-BassPublishers.

Maslach, C., Jackson, S. E., Leiter, M. P. (1996). Maslachburnoutinventorymanual. Thirdedition. Consulting Psychologists Press.

Maslach, C., Schaufeli, W. B., Leiter, M. P. (2001). Job burnout. Annu. Review Psychology, vol. 52: 397-422.

Mukundan, J., Khandehroo, K. (2010). Burnout Among English Language Teachers in Malaysia. Contemporary Issues in Education Research, vol. 3(1): 25-38. 
Nagar, K. (2012). Organizational commitment and job satisfaction among teachers during times of burnout. Vikalpa, vol. 37(2): 43-60.

Näring, G., Briët, M., Brouwers, A. (2006). Beyond demands-control: Emotional labor and symptoms of burnout in teachers. Work \& Stress, vol. 20(4): 303-315.

Özbey, S. (2012). An investigation on the relationships among burnout levels of preschool teacher trainees, certain variables and social support. International Journal of academic research, vol. 4(1): 154-161.

Papastylianou, A., Kaila, M., Polychronopoulos, M. (2009). Teachers' burnout, depression, role ambiguity and conflict. Social Psychology of Education, vol. 12: 295-314.

Ponce, A. N., Lorber, W., Paul, J. J., Esterlis, I., Barzvi, A., Allen, G. J., Pescatello, L. S. (2008). Comparisons of Varying Dosages of Relaxation in a Corporate Setting: Effects on Stress Reduction. International Journal of Stress Management, vol. 15(4): 396-407.

Psichologijos žodynas. (1993). Vilnius: Mokslo ir enciklopedijų leidykla.

Rey, L., Extremera, N., Pena, M. (2012). Burnout and work engagement in teachers: are sex and level taught important? Ansiedad y Estrés, vol. 18(2-3): 119-129.

Rupšienè, L. (2007). Kokybinio tyrimo duomenu rinkimo metodologija. Klaipėdos universiteto leidykla.

Shapiro, S. L., Brown, K. W., Biegel, G. M. (2007). Teaching Self-Care to Caregivers: Effects of Mindfulness-Based Stress Reduction on the Mental Health of Therapists in Training. Training and Educationin Professional Psychology, vol. 1(2): 105-115.

Sulea, C., Filipescu, R., Horga, A., Orțan, C., Fischmann, G. (2012). Interpersonal mistreatment at work and burnotu among teachers. Cognition, Brain, Behavior. An Interdisciplinary Journal, vol. 16 (4): 553-570.

Tonder, C. L., Williams, C. (2009). Exploring the origins of burnout among secondary educators. Journal of Industrial Psychology, vol. 35 (1): 204-218.

Zellmer, D. D. (2005). Teaching to Prevent Burnout in the Helping Professions. Analytic teaching, vol. 24(1): 20-25.

Smith, J. C. (2007). The New Psychology of Relaxation and Renewal. Biofeedback, vol. 35(3): 85-89.

Stueck, M. (2010). The concept of systemrelated stress reduction (sysred) in educational fields. Problems of education in the 21st century, vol. 29: 119-134.

Водопьянова, Н., Старченкова, Е. (2005). Синдром выгорания: диагностика и профилактика. СанктПетербург: Питер.

Курис, И. В. (2001). Релаксационное движение как инструмент психотерапии / Вопросыментальной медицины и экологии Prieiga internete: http://ezotera.ariom.ru/2010/01/17/kuris.html> [žiūrèta 2012-04-20].

\section{PREVENTION AND REDUCTION OF PHYSICAL EDUCATION TEACHERS' BURNOUT: RESULTS OF AN EDUCATIONAL PROJECT}

\section{Andrius Stočkus}

\section{Summary}

The article aims at revealing the possibilities for prevention and reduction of physical education teachers' professional burnout, empirically grounding the efficiency of the strategy based on development of relaxation skills of physical education teachers working in comprehensive education institutions of Lithuania.

The notions of professional burnout, or just burnout, more and more often are encountered in scientific research dealing with pedagogues as an object. Research studies (Näring et al., 2006; Brudnik, 2009; Tonder, Williams 2009; Coulter, Abney 2009; Chang, 2009; Mukundan, Khandehroo, 2010, Özbey, 2012; Rey, Extremera, Pena, 2012; Sulea et al, 2012) estimated that teacher's profession is inseparable 
from the burnout syndrome and is listed as one of the most vulnerable when talking about this unpleasant phenomenon. Even though there are many definitions of the professional burnout, one of the most famous researchers of this syndrome, C. Maslach, presented the definition which became the most popular and commonly acknowledged by academic community. Burnout is the condition of emotional, psychic and physical exhaustion formed under the impact of long-term unsolved stresses arising in work situations (Maslach, 1993). This is a postponed response to inveterate (constant) emotional and interpersonal stressors at work characterised by three dimensions: emotional exhaustion, depersonalisation and personal accomplishment (Maslach et al., 2001).

Emotional exhaustion (EE) is based on emotional overwork and exhaustion of own emotional resources. This is a feeling when a person communicating with others is not able to execute the requirements posed, finds himself / herself completely emotionally and physically exhausted and, therefore, undergoes frustration (disappointment) and tension. A person lacks energy to start new activities or communicate with other person. Burnout is the first reaction to stress experienced at work. Emotional exhaustion is considered to be a major component of the burnout syndrome (Maslach et al., 2001).

Depersonalisation $(D P)$ is based on negative, cynical behaviour, emotional withdrawal including disappointment, distrust, despair or exaggerated coldness in communication with other people at work. This is an indifferent reaction to people with whom one works; relations with people become formal, as if impersonal. In a certain sense this is the striving to protect oneself from exhaustion and despair. The component of depersonalisation means the interpersonal burnout aspect. This component is also called dehumanisation.

Personal accomplishment (PA) is based on the decrease of own competence and productivity, the sense of effectiveness at work, inefficiency. This is diminished self-reliance, confidence in competence and ability to work successfully, depreciation of own achievements and significance at work. A person feels ineffective in his / her performance and thinks that one's personal contribution to performance of an organisation no longer has a sense (Nagar, 2012). Personal accomplishment means self-assessment in the burnout aspect.

Even though first research works on the burnout started in the beginning of the 1970s, pedagogues' professional burnout became the focus of intensive interest only ten years later. Early research treated work load as the essential reason for teachers' professional burnout (Chang, 2009); however, as time went by, several directions of research on teachers' professional burnout regarding the causes influencing manifestation of the professional burnout have been estimated. These are individual factors (socio-demographic variables, personality traits etc.) and or- 
ganisational factors (work conditions, loads, complication of contacts with other people etc.). Contemporary research studies on teachers' professional burnout are more focused on teachers' burnout as an outcome of interaction between separate factors (individual and organisational) (Chang, 2009).

The research studies (Chang, 2009; Mukundan, Khandehroo, 2010; Özbey, 2012; Rey, Extremera, Pena, 2012; Sulea et al., 2012) estimate that teacher's profession is inseparable from the burnout syndrome and is listed among the most dangerous professions dealing with this unpleasant phenomenon. Ways to perform a preventive and reducing role in this process are being constantly sought for. Among all strategies, increasing attention of scientists is drawn by the ways for avoiding, coping with professional burnout, the diminishing of its consequences involving individual's self-help without support of others. Such ways include relaxations techniques, such as skills to control tension, physical and emotional stress, techniques of concentration, meditation which increase self-efficiency in coping with negative emotional states, stress and burnout. This is one of the most efficient methods to control inner tension, anxiety, stress or even depression.

To empirically ground the prevention and reduction strategy against physical education teachers' professional burnout and to assess (in)efficiency of its impact, the method of an educational project has been chosen. The content of the educational project's programme consists of a theoretical part of the programme and four information (relaxation ways) blocks: breathing exercises; visualisation; skills for changing muscle tonicity; autotraining. Duration of the educational project was 24 weeks. 23 teachers of physical education working in Šiauliai city and district comprehensive education institutions took part in the project.

Obtained research results revealed that the strategy for prevention and reduction of professional burnout positively impacted the level of professional burnout by promoting physical education teachers' self-education, critical thinking, lifelong learning and development of relaxation skills. Between the first and the second diagnostic sections (in the beginning and end of the educational project), there are statistically significant $(p<0.05)$ differences between results of emotional exhaustion (EE) and decrease of the sense of personal professional aims (PA) in subscales. Results of the depersonalisation (DP) scale were positive (the level of depersonalisation decreased) in the end of the educational project; however, no statistically significant difference between results was noticed.

All participants of the educational project positively assessed the impact of the educational programme on prevention and reduction of stress and professional burnout. After the educational project was over, all pedagogues were able to identify the tension in their bodies as well as to successfully eliminate and reduce 
it. Because of simplicity and quick effect, breathing and visualisation techniques were listed as the most efficient means for physical education teachers to reduce tension and to feel relaxation; these also were the main relaxation technique complementing other relaxation exercises. The educational project provided new competences to teachers of physical education; these competences were successfully implemented in lessons of physical education. Major possibilities for application of relaxation exercises in prevention and reduction of stress and professional burnout were listed as follows: reduction of tension and negative emotions after a work day, reduction of psychosomatic disorders and coping with insomnia, sense of freshness and energy at the beginning of a day. 